УДК 332.14

Кондіус I.C., к.е.н., доцент

Луцький національний технічний університет

\title{
КОНЦЕПТУАЛЬНІ ЗАСАДИ ТЕОРІЇ АНАЛІЗУ ТА ОЦІНКИ ЕФЕКТИВНОСТІ БАНКІВСЬКОЇ СИСТЕМИ
}

У публікації розглянуто підгрунтя для розроблення теоретико-методологічних підходів до аналізу та оцінки ефективного функціонування банківської системи, що грунтуються на застосуванні одночасно декількох методів та різних наборів змінних, що оцінюються, а саме: надійність та перспективність. Запропоновані методи оцінки рівня банківської системи та обгрунтована доцільність застосування таких сучасних методів як DEA і SFA або їх модифікацій.

Ключові слова: банк, ефективність, надійність, перспективність, система.

Kondius I.

\section{CONCEPTUAL FOUNDATIONS OF ANALYSIS THEORY AND ASSESSMENT OF THE EFFICIENCY OF THE BANKING SYSTEM}

The publication discusses the basis for developing theoretical and methodological approaches to the analysis and evaluation of the effective functioning of the banking system, based on the application of several methods and different sets of variables that are evaluated, namely: reliability and perspective. Methods for assessing the level of the banking system are proposed and the feasibility of using modern methods such as DEA and SFA or their modifications is substantiated.

Keywords: bank, efficiency, reliability, perspective, system.

Кондиус И.С.

\section{КОНЦЕПТУАЛЬНЫЕ ОСНОВЫ ТЕОРИИ АНАЛИЗА И ОЦЕНКИ ЭФФЕКТИВНОСТИ БАНКОВСКОЙ СИСТЕМЫ}

В публикации рассмотрены основы для разработки теоретико-методологических подходов к анализу и оценке эффективного функционирования банковской системы, основанные на применении одновременно нескольких методов и различных наборов переменных, которые оцениваются, а именно: надежность и перспективность. Предложенные методы оценки уровня банковской системы и обоснована целесообразность применения таких современных методов как DEA и SFA или их модификаций.

Ключевые слова: банк, эффективность, надежность, перспективность, система.

\section{Постановка проблеми у загальному вигляді i iї зв'язок 3 важливими науковими та практичними завданнями.}

Розвиток української банківської системи супроводжується посиленням конкуренції, зростанням активів системи, які тільки за період 2010-2018 рр. збільшилися в 8 разів, приходом нових іноземних гравців на ринок, при цьому кількість діючих банків 3 іноземним капіталом зросла за вищезазначений період 319 до 53, і в той же час поступовою ліквідацією неспроможних банків. Банківські установи функціонують, 3 одного боку, в умовах економічної кризи в країні та світі в цілому, а з іншого - в умовах посилення регуляторних вимог. Як результат, увага банків до характеристик власної діяльності, а також діяльності своїх конкурентів значно виросла. Варто відмітити, що оцінка конкурентів відбувається на постійній основі в кожному банку - чи то регулярний моніторинг ринку, чи підготовка конкретних проектів по злиттю і поглинанню, стратегічному розвитку тощо. Внаслідок цього зросла i актуальність оцінки ефективності банку у порівнянні зі своїми суперниками. Однак, відсутність загальноприйнятої термінології щодо ефективності банківської діяльності та єдиної затвердженої методики оцінки останньої призводить до необхідності вирішення ряду проблем методологічного характеру.

Цілі статті. Створити методологічне підгрунтя щодо оцінки та аналізу 
ефективності банківської системи, що включає показники надійності та перспективності iii функціонування.

\section{Виклад основного матеріалу дослідження 3 повним обгрунтуванням отриманих наукових результатів.}

В першу чергу, звертаючись до поняття ефективності банківської діяльності необхідно розглянути його визначення.

Говорячи про банківську діяльність поняття ефективності, на нашу думку, набуває наступного сенсу: це можливість та вміння виробити та продати максимальну кількість банківських продуктів заданої якості при мінімальних витратах. Хоча у вітчизняному банківському товаристві в більшості випадків під ефективністю розуміють або рівень досягнення в короткостроковій перспективі певних фінансових показників, таких як прибуток, рентабельність тощо, або ступінь задоволення інших інтересів власників даної організації [1,2].

У загальному випадку під ефективністю розуміють найбільш оптимальний розподіл обмежених ресурсів економічним суб'єктом при досягненні заданого рівня виробництва товарів i/aбо послуг. Розглядаючи банківські установи, можна відмітити, що ефективність банку можна розглядати у різних аспектах: як ефективність відносно витрат, ефективність відносно доходів чи ефективність відносно прибутку.

Багатоаспектний характер показника ефективності банківської діяльності призводить до розробки та застосування з метою його оцінки великої кількості різних методів.

Дослідження ефективності банківської діяльності привертають увагу багатьох вітчизняних і зарубіжних науковців та практиків. Питанням визначення ефективності як загального економічного поняття та ефективності банківської діяльності, зокрема, присвячено праці таких вітчизняних та російських вчених як О. Вовчак [3], Д. А. Круглов [4], М. М. Кузьмин [Error! Reference source not found.], Ю.Маців [3], С. Р. Моїсеев [4], А. Пілявський [Error! Reference source not found.], В. Р. Саркісян [5], К. В. Толчин [6], Т. Хома [3]. Праці закордонних науковців можна поділити на дві групи, а саме, теорія та методи оцінки ефективності та прикладне використання методів до оцінки ефективності діяльності банківських установ. До першої групи слід віднести роботи С. Вейнера, Б. Парка, С. Родеса, Л. Сімара, С. Гроскопфа, У. Купера, А. Чарнеса [Error! Reference source not found.], М. Фаррела [10], та ін. Серед авторів робіт другої групи доцільно відзначити: А.Бергера Д., Хампрі Ф., Еліазіані, С. Куана [12].

Наукові напрацювання в загальній теорії ефективності, рекомендації стосовно способів її оцінювання хоча і досить значні, проте проблеми визначення ефективності 3 урахуванням специфіки банківської діяльності залишаються недостатньо розробленими як в теоретичному, так і в методично-практичному аспектах. Однією 3 основних невирішених частин даної проблеми залишається вибір методу оцінки ефективності діяльності банку, що дозволяє отримати адекватні результати.

Вибір методів оцінки ефективності діяльності банку в першу чергу залежить від мети проведення такої оцінки. Кожен метод має свої переваги та недоліки, які обумовлюють прийнятність або неприйнятність його застосування у конкретних умовах для досягнення конкретних цілей. Загалом методи, що використовуються для оцінки ефективності банківської діяльності можна поділити на чотири групи (рис. 1):

- підхід фінансових коефіцієнтів, що включає в себе розрахунок традиційних коефіцієнтів - показників ефективності та розрахунок індексів продуктивності;

- експертні методи, що грунтуються на суб'єктивній оцінці фахівців певного напрямку;

- параметричні методи, що базуються на економетричному аналізі й потребують визначення функціональної форми виробничої функції банку або функцій витрат, прибутків, доходів; 
- непараметричні методи, що використовують математичне програмування і не потребують визначення функціональної форми виробничих залежностей.

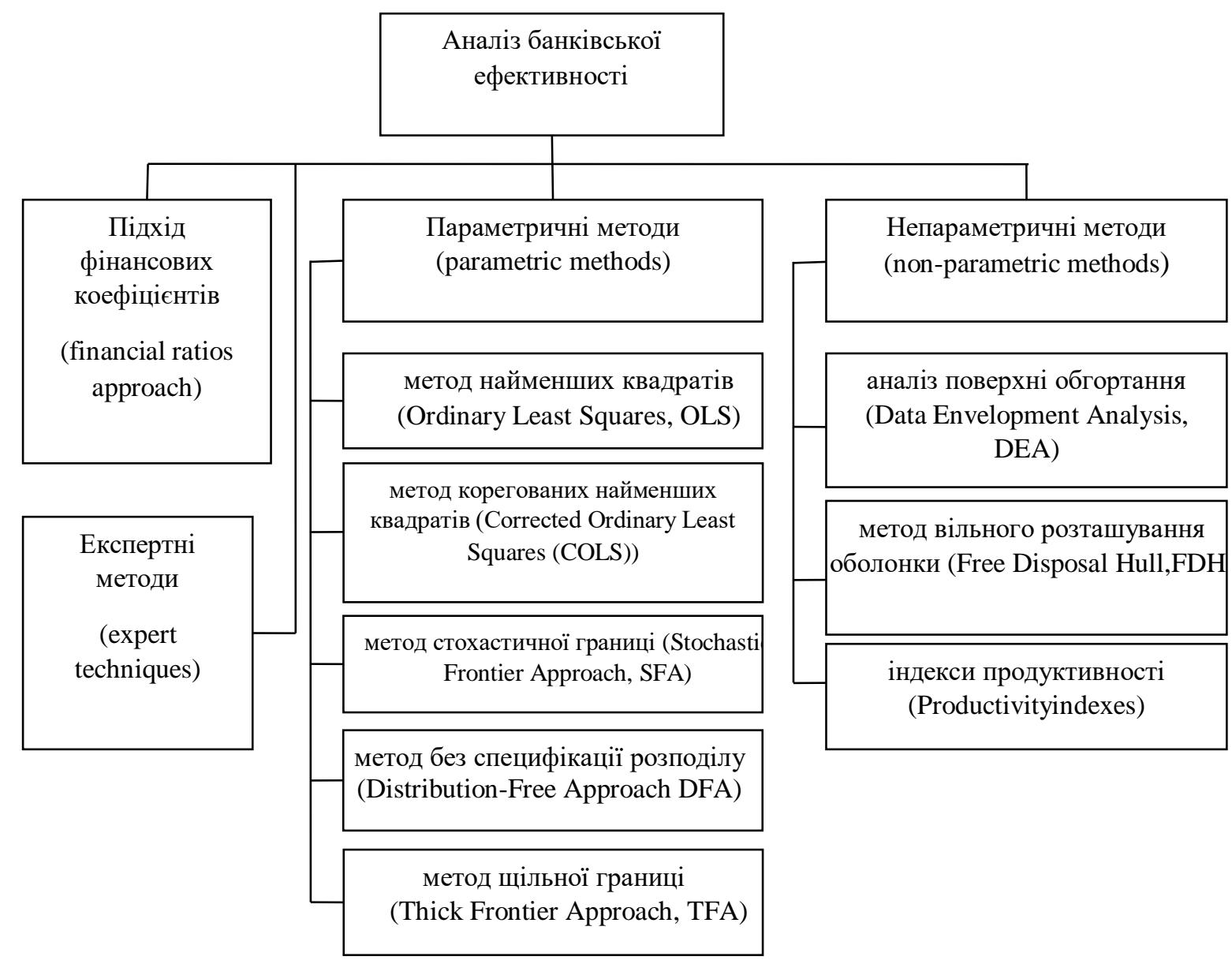

Рис. 1. Класифікація методів оцінки ефективності діяльності банку

Із широкого кола задач, які виникають при аналізі даної проблеми, однією 3 найбільш важливих $є$ формування категоріального апарату ефективності банківської системи, який повинен включати визначення таких базових понять як ефективність, надійність та перспективність банківської системи, працездатність системи, ії відмова тощо. Ефективність банківської системи спирається на дві властивості - надійність та перспективність.

Поняття надійності загалом застосовується до технічних виробів, споруд чи систем. I по змісту, значенню, та розумінню надійність - це властивість технічного об'єкта зберігати тривалий час в визначених межах значення параметрів, які характеризують його спроможність виконувати потрібні функції в заданих режимах та умовах застосування, технічного обслуговування, зберігання і транспортування [140]. Говорячи про банківську систему, під терміном «надійності» пропонується розуміти можливість банківської системи ефективно, своєчасно та безперервно, в повному обсязі в умовах високого рівня зовнішнього та внутрішнього економічного тиску виконувати свої функції, зокрема, трансформаційну, стабілізаційну, функцію створення платіжних засобів і функцію регулювання грошової маси в обігу.

До того ж, поняття надійності банківської системи може бути деталізовано відносно суб'єкту, що співдіє з системою - контрагенту. 3 точки зору клієнтів банку, його вкладників, надійна банківська система в більшій мірі асоціюється з переконанням у тому, що банк, з яким вони працюють, виконає перед ними свої зобов'язання. 3 точки зору акціонерів банку, надійна банківська система створює такі умови для 
функціонування банків, за яких вони є дохідним місцем вкладення капіталу і отримання прибутку у порівнянні з іншими секторами економіки. 3 позицій співробітників банків (як елементів банківської системи), зацікавлених в отриманні високого заробітку, надійний банк повинен давати їм можливість бути безсумнівно впевненими у стабільному і добре оплачуваному працевлаштуванні. 3 боку громадян, інвесторів, банківської системи та суспільства в цілому, інтереси якого в даному випадку представляє Національний банк, надійна банківська система забезпечує збереження балансу інтересів і кредитних організацій, і їх клієнтів.

Отже, надійна система повинна бути здатною виконувати означені ій функції, бути дієвою в будь-яких нестабільних умовах, тобто бути працездатною на визначеному проміжку часу.

Під терміном перспективність мається на увазі стан системи та ії елементів, при якому значення всіх параметрів, що характеризують іiі здібність виконувати задані функції, відповідають нормативним вимогам і вимогам іiі користувачів. При цьому повинно забезпечуватися задоволення та захист інтересів вкладників і клієнтів банків, створюватися сприятливі умови для розвитку економіки України та підтримки вітчизняного товаровиробника. Коли система стає неперспективною, виникає необхідність визначення іï непрацездатних елементів 3 подальшим їх фінансовим оздоровленням для відновлення їх працездатності, реорганізацією, ліквідацією та створенням за необхідності нових працездатних. В обох випадках витрачаються праця, матеріальні засоби і кошти, що є платою за недостатню надійність об'єкта. Втрати можуть навіть перебільшити кошти, вкладені при створенні банку. До того ж, втрата працездатності одного елементу банківської системи може мати наслідки набагато гірші, ніж витрати на відновлення його функціонування. Оскільки, по-перше, може привести до грошових і моральних втрат його клієнтів, вкладників та інших контрагентів, а, подруге, може зумовити втрату працездатності інших елементів системи і зниження ефективності всієї банківської системи.

Як показує практика, елементами банківської системи, що реглярно втрачають перспективність, є комерційні банки. При цьому банкрутства окремих банків відбуваються не частіше, ніж банкрутства інших підприємств, але вони можуть бути найбільш руйнівними для економіки. Часто банківські кризи супроводжують загальні економічні кризи та загострюють їх, хоча можуть протікати й осібно.

Безпосередніми причинами втрати перспективності банку є неповернення наданих ним позик, знецінення інвестицій, збитки при термінових угодах тощо. Однак, одними $з$ найсерйозніших є соціально-економічні механізми розвитку відмов, що виявляються у поширенні панік та ажіотажу серед клієнтів банку і викликають лавиноподібні процеси. При цьому будь-яке значне банкрутство банку може викликати ланцюгову реакцію банкрутств серед підприємств та банків, які тісно пов'язані між собою по лінії міжбанківського кредиту. Яскравими прикладами даної ситуації є валютна та депозитна паніка, які можуть зявлятися або окремо, або викликати одна одну. Наприклад, знецінювання національної грошової одиниці внаслідок гіперінфляції викликає різкий відтік банківських депозитів і викид їх на валютний ринок, що приводить і до валютної, i до банківської паніки й може привести до непрацездатного стану всю банківську систему.

Обсяги операцій тільки Національного банку України по запобіганню та придушенню цих процесів за оцінками експертів становлять мільярди гривень. Найкращим інструментом їх попередження стає високий рівень довіри населення та суб'єктів господарювання до банківського сектору, що можливий лише за умови ефективного, надійного, стійкого функціонування банківської системи протягом доволі тривалого періоду часу.

Для кількісної оцінки рівня ефективності банківської системи необхідним $є$ розробка індикаторів - показників ефективності об'єкту дослідження. Тоді оцінка рівня ефективності системи зведеться до задачі знаходження числового значення показників 
надійності та перспективності системи і порівняння знайдених значень 3 граничними, при яких наслідки від можливих втрат працездатності елементами системи будуть найменшими. По-друге, при знанні числових значень показників надійності та перспективності декількох елементів системи (прикладом, комерційних банків) можна стверджувати об'єктивно, який з них більш ефективний, які умови функціонування більш сприятливі тощо.

Визначення даних показників дозволить вивчити і проаналізувати закономірності зміни з часом рівня працездатності банківської системи, знайти методи використання вказаних закономірностей для забезпечення мінімуму втрати часу i коштів для підтримання ефективної діяльності банківської системи в умовах, що реально складаються, та застосувати вказані методи при розробці стратегічних планів ії розвитку.

Аналіз надійності банківської системи покликаний виявити шляхи

- забезпечення ефективного довгострокового функціонування банківської системи та їі елементів при мінімально можливих витратах часу, праці та коштів на їх оздоровлення, відновлення («ремонт»), уникнення або подолання небажаних наслідків відмов, що можуть поставити під загрозу безпеку коштів, довірених банкам, або завдати шкоди належному веденню банківської діяльності;

- забезпечення клієнтів та контрагентів адекватними прогнозами щодо ймовірності ефективного довгострокового функціонування системи, щодо імовірності строків відмов і відносно очікуваних витрат на попередження і локалізацію відмов, а також на відновлення цих елементів чи зв'язків системи після відмов;

- забезпечення органів банківського регулювання та нагляду теоретичною i практичною базою для створення надійних умов ефективного функціонування банківського сектору.

Відповідно головною задачею теорії ефективності банківської системи, іï теоретичних розробок та практичних рекомендацій $є$ прогнозування поведінки системи та іiї елементів протягом визначеного часу діяльності, знаходження шляхів забезпечення ïx ефективного функціонування та підтримка необхідного рівня їх надійності й перспективності.

Задачею теорії ефективності банківської системи також $є$ вивчення природи виникнення відмов, вивчення незворотних процесів, які відбуваються в системі та іiі підсистемах і з часом призводять до втрати властивостей по виконанню заданих функцій.

Висновки: Отже, при оцінці ефективності діяльності банку, в першу чергу, необхідно враховувати ким і для кого вона проводиться і лише після цього здійснювати вибір методу даної оцінки. Та як показав проведений аналіз в більшості випадків для отримання достовірних результатів необхідним $є$ застосування одночасно декількох методів та різних наборів змінних, що оцінюються. При цьому для більшості груп користувачів інформації про ефективність діяльності банків може бути обгрунтована доцільність застосування таких сучасних методів як DEA і SFA або їх модифікацій.

\section{Список бібліографічного опису:}

1. Толчин К. В. Об оценке эффективности деятельности банков. Деньги и кредит, №9, 2007. - С. 58-62

2. Кондіус I.С. Математичні методи оцінки банківської системи [Текст] / І.С. Кондіус.Економічний форум: науковий журнал. Луцьк: ЛНТУ, 2015. - Випуск №4. - С. 396-403

3.Пілявський А., Вовчак О., Маців Ю., Хома Т. Ефективність діяльності банківської системи (2005-2009 рр.). Методологія аналізу фронтів. Вісник НБУ. - 2010. - №4. - С. 16-22.

4. Моисеев С. Р., Круглов А., Кузьмин М. М. Эффективность российских банков: аналитический отчет. Центр эконолических исследований МФПА. Москва, 2007. - 19 с.

5. Саркісян В. Р. Сутність та зміст поняття «ефективність діяльності комерційного банку» 3б. наук. праць Національного університету державної податкової служби Украӥни, 2009. - №1. - С. 251-258

6. Толчин К. В. Об оценке эффективности деятельности банков. Деньги и кредит, №9, 2007. - С. 58-62

7.Park B., Simar L., Weiner C. The FDH estimator for productivity efficiency scores: Asymptotic Properties. Econometric Theory, №16, 1999. - P. 855-877.

8. Grosskopf, Shawna, (1996), "Statistical inference and nonparametric efficiency: A selective survey", The Journal of Productivity Analysis 7, pp 161-176.

9. Charnes A., Cooper W. W., Lewin A. Y., Seiford L. M. Data envelopment analysis: Theory, methodology, and applications. Boston: Kluwer Academic publisher, MA. - 1994.

10. Farrell M.J. The measurement of productive efficiency. Journal of the Royal Statistical Society, 1957. - № 120, pp. $253-289$ 
11. Berger, A. N., Humphrey D. B. Efficiency of Financial Institutions: International Survey and Directions for Future Research. European Journal of Operational Research, 1997. - №98. - pp. 175-212.

12. Eisenbeis R., Ferrier G. and Kwan S. (1999) The informativeness of stochastic frontier and programming frontier efficiency scores: Cost efficiency and other measures of bank holding company performance. Federal Reserve Bank of Atlanta Working Paper \#99-23

\section{Reference:}

1. Tolchin K.V. (2007). Ob otsenke effektyvnosty deiatelnosty bankov [On assessing the effectiveness of banks]. In Denhy y kredyt [Money and credit]. Vol.9. (pp. 58-62). [in Russian].

2. Kondius I.S. (2015). Matematychni metody otsinky bankivskoi systemy [Mathematical Methods of Estimation of a Banking System]. Ekonomichnyi forum - Economic forum. №4. (pp. 396-403). [in Ukrainian].

3. Pilyavsky A., \& Vovchak O., \& Matsev Y., \& Homa T. (2010). Efektyvnist diialnosti bankivskoi systemy (2005-2009 rr.). Metodolohiia analizu frontiv. [Efficiency of banking system activity (2005-2009). Methodology of front analysis]. In Visnyk NBU [Bulletin of the National Bank of Ukraine]. Vol.4. (pp. 16-22). [in Ukrainian].

4. Moyseev S.R, \& Kruglov A., \& Kuzmin M.M. (2007). Effektyvnost rossyiskykh bankov: analytycheskyi otchet. [The efficiency of Russian banks: an analytical report]. Tsentr эkonomycheskykh yssledovanyi MFPA. [MFAA Center for Economic Research]. P.19. [in Russian].

5. Sarkisian V.R. (2009). Sutnist ta zmist poniattia «efektyvnist diialnosti komertsiinoho banku». [The essence and content of the concept of «commercial bank activity efficiency»]. Zb. nauk. prats Natsionalnoho universytetu derzhavnoi podatkovoi sluzhby Ukrainy. [Coll. Sciences. of the National University of the State Tax Service of Ukraine]. Vol.1. (pp. 251-258). [in Ukrainian].

6 .. Tolchyn K. V. (2007). Ob otsenke effektyvnosty deiatelnosty bankov. [On the evaluation of the efficiency of banks]. Denhy $y$ kredyt. [Money and credit]. Vol.9. (pp. 58-62). [in Russian].

7. Park B., Simar L., Weiner C. (1999). The FDH estimator for productivity efficiency scores: Asymptotic Properties. Econometric Theory. №16. P. 855-877.

8. Grosskopf, Shawna, (1996), «Statistical inference and nonparametric efficiency: A selective survey». The Journal of Productivity Analysis №7, pp 161-176.

9. Charnes A., Cooper W. W., Lewin A. Y., Seiford L. M. (1994). Data envelopment analysis: Theory, methodology, and applications. Boston: Kluwer Academic publisher. MA.

10. Farrell M.J. (1957). The measurement of productive efficiency. Journal of the Royal Statistical Society. № 120, pp. $253-289$.

11. Berger, A. N., Humphrey D. B. (1997). Efficiency of Financial Institutions: International Survey and Directions for Future Re search. European Journal of Operational Research. №98. pp. 175-212.

12. Eisenbeis R., Ferrier G. and Kwan S. (1999) The informativeness of stochastic frontier and programming frontier efficiency scores: Cost efficiency and other measures of bank holding company performance. Federal Reserve Bank of Atlanta Working Paper №99-23.

\section{Рецензент д.е.н., професор Вахович I.M.}

\section{УДК 336.77 .067}

Мігулка О.О., аспірант кафедри економіки та менеджменту Дрогобицький державний педагогічний університет імені Івана Франка

\section{СУТНІСТЬ ТА КЛАСИФІКАЦІЯ РИЗИКІВ ФІНАНСОВОГО ЛІЗИНГУ}

У статті проаналізовано особливості ідентифікації та оцінювання ризиків компаній, задіяних у лізинговому бізнесі та запропоновано власну систему класифікації ризиків лізингодавців, лізингоотримувачів, кредиторів, продавців (виробників) та страхових компаній. Показано, що незважаючи на те, що в основу кредитних та лізингових операцій покладено однакові принципи, такі як платність, строковість та повернення, проте у лізинговому бізнесі на відміну від кредитування виникає необхідність врахування усіма учасниками лізингової угоди нової групи майнових та пов'язаних із ними ризиків. Відзначено, що, з одного боку, відсутність законодавчо встановлених вимог щодо резервування капіталу українськими лізинговими компаніями відкриває їм більший доступ до свої фінансових ресурсів, проте, 3 іншого боку, така ситуацію може спричинити значну недооцінку ними рівня ризику свого портфеля активів.

Ключові слова. Лізинг, лізингодавець, лізингоодержувач, лізингові ризики, достатність капіталу, фінансовий лізинг, операційний лізинг.

\section{Мигулка O.O.}

\section{СУЩНОСТЬ И КЛАССИФИКАЦИЯ РИСКОВ ФИНАНСОВОГО ЛИЗИНГА}

В статье проанализированы особенности идентификации и оценки рисков компаний, задействованных в лизинговом бизнесе и предложено собственную систему классификации рисков лизингодателей, лизингополучателей, кредиторов, продавцов (производителей) и страховых компаний. Показано, что несмотря на то, что в основу кредитных и лизинговых операций возложено одинаковые принципы, такие как платность, срочность и вовзрат, однако в лизинговом бизнесе в отличие от кредитования возникает необходимость учета всеми участниками лизинговой сделки новой группы имущественных и связанных с ними рисков. Отмечено, что, с одной стороны, отсутствие законодательно установленных требований по резервированию капитала украинскими лизинговыми компаниями открывает им больший доступ к своим финансовым ресурсам, однако, с другой стороны, такая ситуация может привести к значительной недооценки ими уровня риска своего портфеля активов.

Ключевые слова. Лизинг, лизингодатель, лизингополучатель, лизинговые риски, достаточность капитала, финансовый лизинг, операционный лизинг. 